\title{
SATANISMO E DECADENTISMO EM REZAS DO DIABO, DE WENCESLAU DE QUEIRÓS
}

\section{SATANISM AND DECADENTISM IN WENCESLAU DE QUEIRÓS' REZAS DO DIABO}

\author{
Recebido: 12/03/2020 | Aprovado: 03/06/2020 | Publicado: 10/07/2020 \\ DOI: https://doi.org/10.18817/rlj.v4i1.2226
}

\author{
Gabriel Esteves ${ }^{1}$ \\ Orcid ID: https://orcid.org/0000-0003-4719-6672
}

\begin{abstract}
Resumo: Na última quadra do século XIX, quando já fenecera o ultrarromantismo byrônico da Academia Paulista e o cientificismo alçava esperançosos voos, a provinciana São Paulo foi palco de uma perturbadora manifestação poética. Respeitadíssimo entre os seus, Wenceslau de Queirós fazia correr a pena diabólica pelos jornais da capital e, sobretudo, pelas páginas do Correio Paulistano. O ilustre poeta, hoje tomado como precursor do simbolismo brasileiro, anunciava periodicamente o lançamento de um volume que só viria a ser publicado depois de sua morte, em 1939: as Rezas do Diabo. O título provocativo fazia referência à poesia que se vinha produzindo sob o estro baudelairiano e, como não poderia ser diferente, causou certo alvoroço entre os castos leitores: satanismo, erotismo, terror, blasfêmias - tudo estava nas páginas do seu livro. Mas terá sido Wenceslau de Queirós um verdadeiro satanista? Se não o foi, o que buscou representar com as suas invocações diabólicas? Terá sido um decadentista ou um realista? Eis algumas das questões que pretendo desenvolver ao longo deste trabalho, sobretudo com o objetivo de mostrar que Wenceslau de Queirós foi um poeta mais complexo do que se costuma pensar.
\end{abstract}

Palavras-chave: Wenceslau de Queirós. Satanismo. Decadentismo. Baudelaire. Simbolismo.

Abstract: In the last quarter of the 19th century, when the byronic ultrarromanticism of the Academia Paulista had already vanished, and scientificism was taking up hopeful flights, the provincial São Paulo was the scene of a disturbing poetic manifestation. Very respected among his own, Wenceslau de Queirós made his diabolical pen run through the capital's newspapers and, above all, through the pages of the Correio Paulistano. The illustrious poet, today taken as a precursor of the brazilian symbolism, periodically announced the release of a volume that would only be published after his death in 1939: Rezas do Diabo. The provocative title referred to the poetry that was being produced under Baudelairian estrus and, as could not be otherwise, caused a certain uproar among the chaste readers: satanism, eroticism, terror, blasphemies - everything was in the pages of his book. But was Wenceslau de Queirós a true satanist? If not, what did he seek to represent with his diabolical invocations? Was he a decadentist or a realist? Here are some of the questions that I intend to develop throughout this paper, especially with the aim of showing that Wenceslau de Queirós was a more complex poet than is usually thought.

Keywords: Wenceslau de Queirós. Satanism. Decadentism. Baudelaire. Symbolism.

\section{O Baudelaire paulistano?}

\footnotetext{
1 Possui graduação em Letras-Língua Portuguesa (2017) e mestrado em Literatura (2020) pela Universidade Federal de Santa Catarina (UFSC). Hoje cursa o doutorado no Programa de PósGraduação em Literatura da mesma instituição e integra o Núcleo de Pesquisas em Informática, Literatura e Linguística (NuPILL). E-mail: gabrielesteues@gmail.com
} 
Em 1867, Jules Vallès escreveu um texto em que dava conta da vida e da morte de Charles Baudelaire. A sua descrição contrasta vivamente com o nosso olhar retrospectivo e chama atenção, mais uma vez, para a incapacidade proverbial que a crítica literária tem de antever as glórias póstumas de um autor. Para ele, o poeta de As flores do mal nunca alcançaria sucesso, senão através do trabalho arqueológico de algum curioso:

Il eut une minute de gloire, un siècle d'agonie : aura-t-il dix ans d'immortalité?

A peine!

Ses admirateurs peuvent tout au plus espérer qu'un jour un curieux ou un raffiné logera ce fou dans un volume tiré à cent exemplaires, en compagnie de quelques excentriques crottés. (VALLÈS, 1867, n.p. $)^{2}$

Dizer que ele estava errado seria ainda muito pouco. No Brasil, As flores do mal foi o livro de cabeceira de inúmeros escritores, exercendo influência sobre poetas vinculados a correntes tão díspares quanto o romantismo, o realismo, o parnasianismo, o decadentismo e o simbolismo. Recebido a princípio como manifestação de pulsões mórbidas e eróticas, o trabalho de Baudelaire deu vazão a uma nova vertente da poesia brasileira que se caracterizou, sobretudo, pela sensualização da mulher e pela bestialização do ato amoroso. A respeito disso, são bastante conhecidos os versos da Profissão de fé, de Carvalho Junior, e $A$ matilha, de Teófilo Dias - no primeiro, o poeta diz preferir a "exuberância dos contornos" de uma mulher real às "virgens pálidas" e "cloróticas" que entendia fazer parte do credo romântico; no segundo, o poeta compara os seus desejos voluptuosos a uma matilha alucinada. Alfredo Bosi se refere à leitura que esses dois poetas fazem de Baudelaire nos seguintes termos:

De Baudelaire assimilam os nossos poetas realistas, Carvalho Jr. e Teófilo Dias, precisamente os traços mais sensuais, desfigurando-os por uma leitura positivista que não responde ao universo estético e religioso das Flores do Mal. O eros baudelairiano, macerado pelo remorso e pela sombra do pecado, está longe destas expansões carnais, quando não carnívoras [...]. Assim, é de um Baudelaire treslido que decorre o primeiro veio realista-parnasiano entre nós; dele e da poesia ainda romântica, mas contida e correta [...]. (BOSI, 1986, p. 245-246)

\footnotetext{
2 Traduzindo: "ele teve um minuto de glória, um século de agonia: terá dez anos de imortalidade? Dificilmente! Seus admiradores podem, no máximo, esperar que algum dia um curioso ou um refinado abrigue esse louco em um volume com tiragem de cem exemplares, na companhia de alguns excêntricos imundos".
} 
É mais ou menos esse o tom da maioria das composições oriundas da nossa primeira safra de baudelairianos - nas palavras de Antonio Candido, "satanismo atenuado e sexualidade acentuada" (CANDIDO, 1989, p. 26). Vale lembrar que Baudelaire, em meados de 1870, gozou por aqui da pecha de "poeta realista", como revela o prefácio que Lopes Trovão escreveu ao Régio saltimbanco, de Fontoura Xavier, no momento em que destaca a "lógica fusão do realismo e romantismo" (TROVÃO, 1877, p. VIII), respectivamente identificados pela "fria observação" de Baudelaire e pelas "surpreendentes deduções" do velho Victor Hugo. O prefácio despertou a atenção de Machado de Assis, e o bom escritor veio a público avisar os contemporâneos, através do já clássico ensaio $A$ nova geração (1879), que Baudelaire sofria distorções com sua passagem aos trópicos:

Quanto a Baudelaire, não sei se diga que a imitação é mais intencional do que feliz. O tom dos imitadores é demasiado cru; e, aliás, não é outra a tradição de Baudelaire entre nós. Tradição errônea. Satânico, vá; mas realista o autor de $D$. Juan aux enfers e da Tristesse de la lune! (ASSIS, 1879, n. p.)

Nesse contexto, portanto, em que Baudelaire se identificava erroneamente com uma poesia sensual e realista - e realismo, lembremos, era "sinônimo de qualquer reação contra o Romantismo" (AMARAL, 1996, p. 76) -, Wenceslau de Queirós ${ }^{3}$ e as suas Rezas do Diabo (1839) representam um novo passo no processo de assimilação d'As flores do mal.

Pode-se dizer que, sem ser um Cruz e Sousa ou um Augusto dos Anjos, Wenceslau já não se limita a ser um Carvalho Júnior: sua obra acrescenta uma dimensão metafísica e religiosa à poesia sexualmente exacerbada do fim do século que "estava, ao que tudo indica, assimilada pelo gosto da época" (AMARAL, 1996, p. 107), revelando uma nova faceta da herança baudelairiana no Brasil - não por acaso, ele é costumeiramente visto como uma das pontes entre

\footnotetext{
${ }^{3}$ Nascido em Jundiaí (1863) e morto em São Paulo (1921), Wenceslau José de Oliveira Queirós exerceu inúmeras ocupações, destacando-se principalmente como juiz federal, poeta e crítico de arte. Assim o descreve Fernando Carvalho: "Wenceslau de Queirós é um grande laborioso; é um infatigável e multiplicado homem de letras que se vê, em bruscas transições, agora na banca de juiz, doutrinando estética, psicologia, literatura e poética; depois, com a pena de afinado crítico, legislando sobre arte dramática; num complexo variar de funções, qual delas mais que bastante para uma especialização. E em tudo ele se revela completo" (CARVALHO, 1962, p. 9).
} 
parnasianismo e simbolismo, ao lado de Medeiros e Albuquerque: "interessam ambos como ponte do Parnaso para o Simbolismo, construída com materiais tomados a um poeta ambivalente como Baudelaire" (BOSI, 1986, p. 304). Já no seu primeiro livro, Versos (1890), Wenceslau de Queirós dá mostras de um aprofundamento dos temas legados pela tradição baudelairiana. Em Nevrose, por exemplo, talvez o mais antológico dos seus primeiros poemas, Wenceslau

dá contornos mais nítidos ao universo da poesia decadista e seu clima de morbidez e neurose, de visões e de sentimentos difusos, acentuando aspectos diferentes do baudelairianismo sensualista do primeiro momento. (AMARAL, 1996, p. 213)

Daí em diante, esses aspectos da poesia decadentista vão se tornando cada vez mais comuns na sua obra, até se transformarem no seu traço distintivo.

Os poemas que integram as Rezas do Diabo, embora só tenham sido definitivamente publicados em 1939, dezoito anos depois da morte do autor, vinham sendo paulatinamente divulgados no Correio Paulistano desde $1894^{4}$ (e não 1904, como sugere Glória Carneiro do Amaral), época em que Wenceslau de Queirós já era conhecido como poeta parnasiano de verve erótica e satânica. Os poemas que publicava nas décadas de 1870 e 1880 Ihe valeram o notório apelido de "Baudelaire paulistano", e tão longe iam os paralelos entre os dois autores que chegavam aos traços físicos - o que, diga-se de passagem, contribuiu significativamente para a formação da imagem pública do nosso poeta. Em 16 de novembro de 1887, Ezequiel Freire publicou um texto destacando aquilo que considerava as afinidades fisionômicas dos dois escritores no Diário Mercantil, e a julgar pela republicação que o Correio Paulistano fez do artigo no dia seguinte, sendo Wenceslau de Queirós um dos seus membros principais, não seria nada precipitado supor que o autor das Rezas do Diabo aprovava as lendas que envolviam o seu nome:

\footnotetext{
${ }^{4}$ Segundo Fernando Carvalho (1962, p. 14), a versão definitiva de Rezas do Diabo estava concluída em 1905. Um ensaio crítico publicado por Joaquim Leitão no Correio Paulistano de 12 de março de 1898, por outro lado, informa que o volume das Rezas do Diabo "já está no prelo" (LEITÃO, 1898, p. 1), e que o crítico está familiarizado com todas as suas composições. Vale notar que o livro de 1939 suprime vários poemas (autorais e traduções) anunciados como parte da coleção entre 1894 e 1904, e que esses poemas (assim como os "poemetos em prosa", críticas, composições cômicas, satíricas e infantis) nunca foram compilados.
} 
Baudelaire e Wenceslau são igualmente feios, com esta diferença: que o primeiro tem algo híspido o lábio superior, rapado completamente à navalha no outro. Mas a boca é a mesma em ambos: grande, carnuda, sensual. Daí, apesar dessa similitude, esta disparidade: Baudelaire aparenta um roupeta lúbrico; Wenceslau um fauno voluptuoso.

A referida afinidade fisiológica é documentada em ambos por um prognatismo característico.

Também nas suas obras, nenhum dos dois disfarça ou atenua, antes parece que faz timbre daquele pendor luxurioso do espírito. Baudelaire escreveu as Flores do Mal, aquela fermentação poética esverdeando-se sobre um belo talento e uma alma corrupta. Wenceslau, que não chega a ser um satânico, é, entretanto, caracteristicamente, um erótico. É dos que, às barbas do leitor pudico, dá de rédea ao erotismo e confessa desejos "de morder as carnes brancas e os seios túmidos" das namoradas. (FREIRE, 1887, p. 1)

Para Fernando Carvalho, a alcunha de "Baudelaire paulistano" foi um exagero resultante do "acanhamento provinciano do nosso meio literário", e acabaria sendo o principal responsável pela "atitude postiça" de poeta satanista que Wenceslau de Queirós viria a adotar com as suas Rezas,

comprometido que se achou com ingênuas exclamações de espanto ou de escândalo levantadas a propósito de inocentes mostras de intenção satanista e de um erotismo bem modesto. (CARVALHO, 1962, p. 13)

Joaquim Leitão, ao contrário, que escreveu uma crítica ao livro em 1898 e falava dele como se já estivesse a ponto de vir ao mundo, alega que o sisudo Wenceslau de Queirós vivia "no constante tormento de penetrar os mistérios da vida e do Universo" (LEITÃO, 1898, p. 1), e não acredita que o poeta-pensador "que é a atual encarnação do poeta" (ibid., p. 1) - tivesse escolhido o título de seu livro "apenas para nos dar a sugestão de pensamentos extravagantes, mefistofélicos" (ibid., p. 1). Leitão sugere que, se referindo ao Diabo, Wenceslau quis simbolizar "a sua opinião sobre o Universo e o seu modo de sentir pela Religião e pela Humanidade" (ibid., p. 1), e chega mesmo a listar uma série de poemas que, ora pelo conteúdo erótico, ora pelo tom blasfemo, não estão à altura do plano geral das Rezas do Diabo:

A "Esperança" e a "Tísica", "Beijos sem conta...", "Primeira comunhão", "Nova eucaristia" e, mais que todos, a "Missa do 
amor", são sensuais, lúbricos, e não podem, não devem acompanhar aquela obra dum pensador, austera e sem as fraquezas da Carne. (ibid., p. 1)

Leitão acredita que Wenceslau de Queirós buscou, inserindo em sua obra essas composições imorais, "estigmatizar o vício, denunciar a matéria", e que os poemas eróticos devem ser lidos, na verdade, como "a acusação dum crime feita por um idealista" (ibid., p. 1), mas acrescenta:

Acho que o autor não acentuou essa intenção, porque não se sabe bem - a não ser pela maneira das outras partes a que devia subordinar-se toda a obra - se estes versos são, de fato, como disse, vergastadas ao materialismo, ou à apoteose da Carne. (ibid., p. 1)

Nesse caso (e voltarei mais tarde a esse ponto) será preciso considerar a hipótese de que Rezas do Diabo realmente se destaca do panorama de produtos decadistas e realistas da segunda metade do século XIX, inaugurando uma vertente mística e idealista, se assim se pode defini-la, da corrente decadentista.

Quanto ao apelido de "Baudelaire paulistano", fosse ele um exagero ou não, se popularizou e abriu caminho para novas fantasias - Baudelaire no século XIX, Wenceslau de Queirós passou a ser o próprio diabo no século XX, como sugere uma descrição bem-humorada da sua passagem pelo carnaval de 1920:

\footnotetext{
Solene e carrancudo, de óculos negros e sobrecasaca negra, a que faltavam, por esquecimento, dois botões, o doutor Wenceslau de Queirós, como um novo Mefistófeles, rezou soturnamente esta oração satânica:

Por esta terra mefítica

De circunstâncias aquáticas,

Não se pode fazer crítica

Sem conhecer as gramáticas!

Depois desta aparição sobrenatural, as entranhas das potências infernais roncaram três trovões; um cheiro acre de betume e enxofre asfixiou a atmosfera, até que, na curva da rua Direita, romperam triunfais $\mathrm{e}$ apoteóticos os clarins dos últimos carnavalescos da noite! (CARNAVAL, 1920, p. 1)
}

Mas foi como êmulo de Baudelaire, afinal, e principalmente do Baudelaire satânico (queira isso dizer sensual, filosófico ou anticristão), que Wenceslau de Queirós passou à posteridade. Para Massaud Moisés, ele foi um "parnasiano de 
estirpe baudelairiana" (MOISÉS, 1969, p. 52), seguindo de perto o consenso das principais histórias literárias, e Luciana Stegagno-Picchio o descreve como inaugurador de um "baudelairianismo paulistano" (1997, p. 334) que retomava a tradição local do satanismo byroniano. Aqui está o ponto central deste artigo: o satanismo. Por um lado, Wenceslau reaviva uma tradição local (é romântico?); por outro, ele manifesta um sentimento de época (é decadentista?); e, por fim, ele introduz uma linguagem nova, pouco a pouco assimilada (é simbolista?), mas o satanismo perpassa todas essas vertentes, o que me permite supor, a princípio, que ele não é mero reflexo de uma influência baudelairiana, mas o resultado de uma confluência de tradições em que o Diabo assume papel relevante. Abaixo, veremos como Wenceslau compõe diferentes figuras diabólicas que servem a diferentes propósitos, revelando um satanismo mais complexo do que se costuma pensar.

\section{Os diabos de Wenceslau}

Já se começa a ver que simples evocações luciféricas não são suficientes para determinar o estilo de um autor ou as características de uma corrente estética. Os diabos representados nos autos medievais, em Dante, Milton, Goethe, Álvares de Azevedo e, enfim, Wenceslau de Queirós, ainda que se aparentem aqui e ali, são bem diferentes entre si. "O Diabo", nos diz Luther Link (1998, p. 46), "é um capetinha impotente ou um demônio perverso com aparências variadas em qualquer época”. Ora, deve-se acrescentar que não só sua aparência muda, mas também suas qualidades. Como Wenceslau apresenta o seu Diabo (ou melhor, os seus diabos)? De que maneira ele se aproxima ou não dos outros diabos da literatura contemporânea? Segundo Fernando Carvalho, o grande mérito de Rezas do Diabo se deve ao fato de ter sido Wenceslau de Queirós o "único poeta nacional" a coligir "toda a temática do satanismo decadentista" explorada pela literatura menor do fim do século, e que "constituiu moda em todas as artes e teve mesmo a sua repercussão fora da vida artística" (CARVALHO, 1962, p. 14). É o mesmo que diz Glória Carneiro do Amaral. Para ela, a obra de Wenceslau de Queirós se notabiliza pelas 
manifestações variadas do satanismo decadista: revolta contra Deus pela condição miserável do ser humano, o entrelaçar da liturgia e da luxúria, episódios da tradição cristã vistos de uma perspectiva profana, pactos faustianos com o Diabo e a presença de um Demônio corporificado numa imagem de origem popular. (AMARAL, 1996, p. 228)

Mas Fernando Carvalho também diz que não era baudelairiana a maior influência dos poemas satânicos de Wenceslau de Queirós, apesar do epíteto com que ficou famoso; seu satanismo estaria melhor catalogado entre as aspirações decadentistas típicas da virada do século. "Se bem que deva ter lido bastante Baudelaire", ele confessa, "como era moda no fim do século passado [XIX] e no princípio deste $[X X]$, não é a poesia baudelairiana que vamos encontrar na sua fase satanista que compreende a maior parte da sua obra poética" (CARVALHO, 1962, p. 15). O satanismo baudelairiano, ele constata, é muito mais profundo do que o praticado pelos decadentistas brasileiros. Faltaria a esses "pretensos discípulos de Baudelaire" o que Fernando Carvalho chamou de "motivo psicológico", pois "o nosso satanismo, com o seu caráter mais conceitual do que psicológico, seria um prolongamento do espírito polêmico que caracterizou o naturalismo de língua portuguesa" (ibid., p. 15), e por isso mesmo pecaria em superficialidade ${ }^{5}$. Polemistas, esses poetas não teriam sido capazes de unir a expressão à ideia. Se para Baudelaire e seus verdadeiros sequazes a expressão da existência seria "obra de sondagem psicológica, estando a concepção de vida do autor inclusa na seleção e no tratamento de determinados dramas da alma", o decadentismo brasileiro teria se limitado a preservar uma "linguagem direta, no mesmo tom conceptual realista ou parnasiano, despojada mesmo do subjetivismo que será retomado pelo simbolismo" (ibid., p. 16) ${ }^{6}$. Essa também parece ser a opinião de Antonio Candido a respeito dos nossos primeiros baudelairianos e,

\footnotetext{
${ }^{5}$ Essa crítica não condiz, como mostrei, com a leitura feita por Joaquim Leitão em 1898, segundo a qual Wenceslau de Queirós não tinha intenções polemistas, mas filosóficas.

${ }^{6}$ Fernando Carvalho, no entanto, admite que Rezas do Diabo, "apesar de jamais ultrapassar o tom polemista" e continuar impregnado de superficialidades, se aproxima suficientemente do modelo francês para expressar duas preocupações fundamentais da poesia baudelairiana: a "queixa desesperada diante da amargura da existência rodeada de enigmas insolúveis que desafiam eternamente a inteligência e o esforço do homem" (CARVALHO, 1962, p. 16), e o horror a uma existência na qual os ideais, "ao invés de constituírem um apoio", são antes uma inesgotável "fonte de desilusões, miragens que, no seu engodo, fazem com que o homem se prenda mais a essa vida de misérias e torpezas", impedindo-o de "buscar de uma vez o nada que será o seu destino de qualquer maneira" (ibid., p. 16).
} 
mais recentemente, a de Glória Carneiro do Amaral a respeito de Wenceslau de Queirós:

\begin{abstract}
.... Satanismo queiroziano situa-se sempre no plano literário, sem integrar o Mal em outros planos da existência e sem aprofundar, através deste tema, a visão do ser humano. Nisto distancia-se do satanismo baudelairiano, pelo que Fernando Carvalho caracterizou como a ausência do motivo psicológico. O satanismo baudelairiano não se restringe a mero motivo literário, mas traduz uma concepção existencial e estética solidamente construída, que se manifesta em praticamente todos os aspectos de sua obra, ultrapassando os limites d'As Flores do Mal. (AMARAL, 1996, p. 228)
\end{abstract}

Glória Carneiro do Amaral, aliás, enfatiza a fantasia popularesca com que Wenceslau de Queirós veste o seu Diabo em alguns poemas, chamando atenção para a disparidade que existe entre o "Baudelaire paulistano" e seu modelo francês. O verdadeiro Diabo baudelairiano, ela diz, é uma "figura imponente, forte e majestosa, rei e príncipe que se apossa do Homem e incute-lhe seus desejos", mas também é, simultaneamente, uma "forma total, cósmica", quer dizer, "é ar, água e alimento", "é sempre entidade impalpável, sem forma física" (AMARAL, 1996, p. 218-219). O Diabo queiroziano, muito ao contrário, se limitaria a ser o truão popular de capa vermelha e tridente na mão:

Quase se espera ver surgir um capeta de capa vermelha e rabo, gargalhando, com seu tridente na mão, conforme o configura a imaginação popular. Um demônio em situações pungentes, como o de "Nostalgia do Céu", cujos olhos ficam "rasos d'água" ao se lembrar do céu. Bastante diferente, portanto, do Satã Trismegisto, entidade encarnadora do Mal na obra baudelairiana. (AMARAL, 1996, p. 220)

É verdade que o Diabo das Rezas é quase sempre a personagem de algum drama e que, embora o livro esteja permeado de reflexões filosóficas, ele está condenado a ser apenas um motivo literário. Por outro lado (e isso, na verdade, reforça o argumento de Glória Carneiro do Amaral), Wenceslau de Queirós não se limita à cópia imediata dos modelos baudelairianos - seu livro conglomera diabos pertencentes a inúmeras tradições. Vejamos alguns exemplos: 
Nos poemas Arte maldita e Vulnus Amoris, ele é o Diabo alado que carrega seus sequazes nas $\operatorname{costas}^{7}$, como o de Goethe ou aqueles de Matteo Maria Boiardo ${ }^{8}$, de origem popular e clara inspiração romântica. Em Visão de São João, ele é o maldoso "dragão de sete cabeças com diademas" (QUEIRÓS, 1939, p. 42) que quer devorar Jesus para escravizar o mundo, ganhando contornos bíblicos e esotéricos. Em Templo de Satã ele é uma força panteísta associada ao amor, à deusa Cibele e à própria natureza: "Quem lê hoje missais? A natureza / Fazes bem de banir da arte cristã, / Porque sabes de há muito, com certeza, / Que a natureza é o templo de Satã" (QUEIRÓS, 1939, p. 46). Nesse mesmo poema, recorrendo ao seu cabedal mitológico, Wenceslau de Queirós menciona a relação entre Satã e Arimã, o deus das trevas no zoroastrismo, erguendo o seu Diabo às alturas do sol: "É da montanha na áspera grandeza / Que canta o sol a missa de Arimã". Como lembra Peter Stanford em O Diabo, a relação entre nosso Satã e aquele rival de Aúra-Masda será sempre difícil de apagar:

Deixar de ver o protótipo do Diabo na figura de Ahriman será sempre uma tarefa difícil, não só porque esse deus persa foi descrito como o próprio Mal, ou como uma força cósmica que fazia oposição ao deus bondoso, mas também porque Zoroastro o tornou semelhante a uma serpente. (STANFORD, 2003, p. 23-24)

Em Beata Beatrix, poema erótico mas não despido de reflexão, o Diabo se associa ainda à natureza e à fertilidade, é o folclórico "bode negro da luxúria" (QUEIRÓS, 1939, p. 71). Em Frei Satanás, ele é um frade apaixonado que escreve livros relatando suas dores:

Na biblioteca de um convento (um frade

Da Idade Média narra em manuscrito)

Achou-se um livro pelo Diabo escrito

Quando fez parte da comunidade...

Era a novela de um amor maldito

Que teve Satanás na Média Idade

Por uma Santa que, na mocidade,

Votou a Deus seu coração contrito.

7 "Fugindo assim à multidão rasteira / Sobre as asas rebeldes do demônio..." (QUEIRÓS, 1939, p. 13).

8 Há mais de uma ocasião no Orlando Innamorato em que um demônio transporta o mago Malagise e também o informa dos últimos acontecimentos, revelando possuir onisciência. 
$[\ldots]$

(QUEIRÓS, 1939, p. 80)

Em Nostalgia do céu, o leitor é surpreendido até mesmo por um Lúcifer com reminiscências angelicais, pensativo e saudoso como o de Milton em seu Paradise Lost, quase a chorar:

Ei-lo que sonha, triste e só... Que estranho augúrio

A alma te agita, arcanjo negro? Que magia,

Que sortilégio, à dura abóbada sombria,

No orco, te prende o chamejante olhar sulfúreo?

$[\ldots]$

Nada demais... Lembra Satã a imensa queda

No boqueirão da eterna sombra que lhe veda,

Eternamente, eternamente, ver os céus...

Punge-o a saudade, a nostalgia, a funda mágoa

De estar (Satã já tem os olhos rasos d'água!)

Longe da Luz, longe do Azul, longe de Deus!

(QUEIRÓS, 1939, p. 14)

Em Glória a ti, ó Satã, encontra-se o anjo caído de Milton e, ao mesmo tempo, o revel que inspira sonhos luxuriantes aos monges no claustro:

Glória a ti, ó Satã, no eterno paroxismo

Do Érebo eterno! Glória a ti, arcanjo exul,

Que sonhas como um deus, nas tênebras do abismo,

Nostálgico do azul!...

Glória a ti, ó revel, que o monge em misticismo

Tentas no claustro e a leste, ao oeste, ao norte, ao sul,

Reinas no mundo a rir das rezas do exorcismo,

Sarcasta arcanjo exul!

$[\ldots]$

(QUEIRÓS, 1939, p. 90)

Em Doutor Fausto e em Herança do Mal, retomando o famoso mito do sábio alemão, vê-se - aí sim! - um Diabo todo popularesco, vestindo capa 
vermelha $^{9}$, que surge a rir entre chamas e carrega seus seguidores dentro do manto. Um Demônio medievalizado, aliás, com gosto de romantismo, é personagem corrente no livro. Em Sonetos de um mago (QUEIRÓS, 1939, p. 21), narrativa bastante gnóstica (como também é $O$ sonho de Paracelso, alquimista medieval), o poeta assume a fantasia de um leitor de magia e ciências ocultas que, em uma noite de inverno, é visitado pelo Diabo - "figura esguia" com "olhos de fogo" e "chamejantes lábios"10. Este, por sua vez, afirma ter "a chave dos arcanos do infinito", e por isso mesmo pode conduzi-lo prometeicamente ao conhecimento das verdades eternas.

Mais de uma vez, o Diabo de Wenceslau de Queirós é retratado como uma espécie de totem da razão e do conhecimento ${ }^{11}$, opondo-se ao trio sentimento-fé-Deus. Em Soneto póstumo (QUEIRÓS, 1939, p. 20), o poeta afirma que "há dentro em mim dous seres: - um que nega, / Outro que afirma", sendo o primeiro associado à razão e o segundo associado ao sentimento. Não por acaso, há entre as Rezas um soneto cujo título associa Satã ao raciocínio, Lógica do Diabo (QUEIRÓS, 1939, p. 24).

Só essas manifestações diabólicas já são indício suficiente de que as influências do "Baudelaire paulistano" são mais heterogêneas do que se costuma pensar, mas é preciso ainda considerar aqueles trabalhos que, sem mencionar o Diabo, encarnam um discurso francamente satânico. É o caso dos poemas em que Wenceslau de Queirós procura, por exemplo, conduzir o leitor a uma revolta metafísica, mostrando que a vida humana não passa de uma eterna e sofrida luta projetada por Deus:

Se Deus existe como a Bíblia ensina,

\footnotetext{
9 "Ao velho Fausto o Tentador dizia, / Estendendo no chão seu rubro manto" (QUEIRÓS, 1939, p. 18) e "Subir! Subir! Subir! - tal é o que ele, entanto, / Aspira, embora vá dentro do rubro manto / Do Diabo, como Fausto, fascinado..." (ibid., p. 19).

${ }^{10}$ A mesma imagem da "boca em fogo" aparece em O beijo de Satã.

11 Segundo Alberto Cousté (1996, p. 107), "as mais antigas tradições da humanidade [...] assinalam a presença de um herói solar que se torna noturna e cai em desgraça pelo mesmo e reiterado pecado: a sede de conhecimento; o segredo da chave do universo (a árvore do bem e do mal, o fogo que não cessa etc.), que rouba dos deuses para dividir com os homens. O mito é tão universal, e seu significado tão transparente, que é impossível não associá-lo ao Diabo das culturas mosaicas". Ainda em referência a Hervé Masson, diz que Lúcifer é a "personificação da Gnose, que livre o homem das cadeias da ignorância". Dirá depois que "como em todos os lugares, também no Egito os deuses relacionados com o conhecimento tinham características diabólicas" (ibid., p. 121).
} 
E o homem tirou do caos, do grande nada, Para a luta da vida, árdua, assassina,

Entre o egoísmo feroz e o amor travada;

Se Deus na alma nos pôs, ardente e alada,

A crença do ideal e, negra sina!

Fê-la depois cair, d'asa quebrada,

Nas próprias garras da ilusão divina;

Se deus, depois de tanto desengano,

Cerrou ouvidos ao lamento humano, ${ }^{12}$

Que há milênios procura o azul dos céus;

Se Deus matou seu próprio filho - Cristo;

(Falo por vós, ó mães!) Se Deus fez isto...

(Falo por vós...) - Maldito sejas, Deus!

(QUEIRÓS, 1939, p. 24)

Aqui, e em outros poemas como Não!, A mulher de Jó, Solilóquio do tédio

e Nihil, Wenceslau está em pleno acordo com o decadentismo definido por Glória

Carneiro do Amaral (1996, p. 63-64):

Apresenta-se o movimento [o decadentismo] como reação a uma arte que traduz uma concepção cientificista do universo, numa postura, portanto, similar à do Simbolismo. [...] O Decadismo é uma tendência marcada por uma intensa revolta e por insatisfação e decepção em relação à crença eufórica no progresso e na ciência. Sua ânsia de evasão encaminha-se para uma busca do exótico, do misterioso, das sensações exageradas e requintadas. Daí suas inclinações mórbidas, seu sadismo sexual e seu interesse pelas ciências ocultas e pelo satanismo.

O satanismo decadentista de Wenceslau de Queirós é uma revolta, $\operatorname{sim}^{13}$; é uma insatisfação com o progresso científico, sim; e por isso mesmo ele não é (quase nunca, note-se bem ${ }^{14}$ ) uma negação da divindade, um decadentismo

\footnotetext{
${ }^{12}$ Encontro a mesma lamentação em Medeiros e Albuquerque (1889a, p. 11): "E Deus? Da curva azul do firmamento / Deus não escuta o sofredor lamento / Das tristes multidões?".

${ }^{13} \mathrm{Na}$ verdade, quase sempre o é. Se há poemas em que o poeta combate toda a injustiça da criação, não é raro encontrar, por outro lado, versos em que Wenceslau de Queirós reconhece a sordidez do Diabo e o despreza francamente, aspirando ao reconhecimento de Deus, vide Visão de São João, Ato de contrição, A Deus (tradução de Edmond Haraucourt) e, sobretudo, São Martinho, poema em que utiliza o santo para afirmar "o céu eu trago aqui no coração!" (QUEIRÓS, 1939 , p. 113), repudiando as tentações de Satã, "o eterno deus do vício". Há mesmo um interessantíssimo poema, Visão de Santa Brigida, em que Wenceslau de Queirós retrata o Diabo arrependido aos pés de Jesus, implorando: "Lava-me pois, Senhor, a mancha do pecado" (QUEIRÓS, 1939, p. 112). Seu desejo é atendido e ele é conduzido por Jesus aos céus.

${ }^{14}$ Justiça seja feita; Wenceslau de Queirós incorre algumas vezes (não com a mesma intensidade) na cosmovisão vazia dos poetas realistas, mesmo em Rezas do Diabo. Veja-se, por exemplo, os poemas Credo e Diálogo. No primeiro, diz: "não creio em Deus; mas creio no teu beijo"
} 
ressentido de ideias realistas. Eu gostaria de me deter aqui sobre este ponto que me parece fundamental no esclarecimento das idiossincrasias de Rezas do Diabo, recuperando um aspecto da crítica feita por Joaquim Leitão em 1898: o caráter metafísico da obra de Wenceslau de Queirós. Giovanni Papini compreendeu bem a interdependência entre o bem e o mal quando afirmou, em seu II Diavolo (1969, p. 81), que "il Diavolo non è per nulla favorevole all'ateismo; è probabile, anzi, che sia nemico degli atei", já que "egli sa troppo bene che la sua potenza è strettamente legata a quella del Signore dei Cieli" ${ }^{15}$. Wenceslau parece também tê-la compreendido, e isso é crucial. Negar a existência de Deus implica na negação do Diabo, e o que se chamou erroneamente o "satanismo" dos poetas realistas não passa, evidentemente, de um ceticismo, de um ateísmo:

Gli uomini che non credono in Dio non si propongono di offenderlo o disubbidirlo, non commettono sacrilegi e, quando sono coerenti, non si curano neanche di bestemmiarlo. (PAPINI, 1969, p. 81). ${ }^{16}$

Sem céu e sem inferno, resta o materialismo e o vazio; é essa a cosmovisão realista que se encontra em boa parte dos poetas de 70 e 80 . Fontoura Xavier, por exemplo, que integrou as linhas da "nova geração", prevê que "inda há de rir de nós o crente de amanhã" em seu Orphée aux enfers, comparando o cristianismo a ritos pagãos, mas não menciona o Diabo em momento algum. Para o poeta de Opalas, "tudo marcha às solidões do nada" (XAVIER, 1884, p. 28). Em O velho Deus, ele se refere ao sol como origem dos mitos humanos, numa postura muito similar a que se vê no Templo de Satã de Wenceslau de Queirós ${ }^{17}$, mas não se refere diretamente ao Diabo ou a qualquer

(QUEIRÓS, 1939, p. 75); no segundo, diz "Abençoa-me, padre, a alma descrida, / Pois tenho uma só crença nesta vida: / Creio no amor de minha mãe e basta" (ibid., p. 89).

15 Traduzindo: "o Diabo não é nem um pouco favorável ao ateísmo; pelo contrário, é provável que seja inimigo dos ateus", e "ele sabe bem demais que sua potência é estreitamente ligada àquela do Senhor dos Céus".

16 Traduzindo: "os homens que não creem em Deus não se propõem a ofendê-lo ou a desobedecê-lo, não cometem sacrilégios e, quando são coerentes, nem mesmo se incomodam em blasfemá-lo".

${ }^{17}$ Compare-se os versos "Quem quiser adorar a tua aurora / Precisa vir cá fora, / Que de ti nem se fala nos missais" (XAVIER, 1884, p. 22) a "Quem lê hoje missais? A natureza / Fazes bem de banir da arte cristã, / Porque sabes de há muito, com certeza, / Que a natureza é o templo de Satã", ou "É da montanha na áspera grandeza / Que canta o sol a missa de Arimã" (QUEIRÓS, 1939, p. 46). 
entidade pagã. Fernando Carvalho, não obstante, afirma que esse procedimento de "paganização" do cristianismo pode ser comum na pena de um parnasiano:

O anticristianismo em Laconte de Lisle não se apresentará como uma revolta contra Deus nem como a busca de um ideal superior ao ideal cristão; na sua roupagem erudita, tão ao gosto da corrente parnasiana, faz desfilar um punhado de deuses e de crenças desaparecidas, sendo incluído o cristianismo como simples traço histórico-cultural destinado ao mesmo desaparecimento. (CARVALHO, 1962, p. 18)

Será talvez comum para um parnasiano, para um realista, mas não para Wenceslau de Queirós: entidades pagãs e diabos confluem para o mesmo universo; ele paganiza o cristianismo para, logo em seguida, "diabolizá-lo".

Em suma, Fontoura Xavier é um descrente com doses de ironia (veja-se, por exemplo, o Monólogo de um cético ${ }^{18}$ ), o que serve também para definir boa parte dos seus coevos, enquanto Wenceslau de Queirós está sempre inserido em um universo cristão (às avessas), sempre aos braços com discussões teológicas, para bem ou para mal. Ora, é precisamente essa atmosfera mística que invade quase todas as composições do livro e define a peculiaridade da obra queiroziana. Mesmo os poemas eróticos que se inserem na tradição realistasensual ${ }^{19}$ inaugurada por Carvalho Júnior são vertidos numa linguagem litúrgica ou aproximados de temas bíblicos em Rezas do Diabo ${ }^{20}$ (exemplos são Missa de amor, Credo, Donna Francesca, A velha serpente, O senhor morto, Primeira comunhão etc.).

18 Veja-se também como Deus é retratado no poema Ave, Italia: "Deus! o vago ideal da Humanidade, / Por quem os grandes cérebros profundos, / Armados da ciência e da verdade, / Interrogavam pélagos de mundos, / Veio à luz como um mísero monstrengo, / Expor-se ao guiso, à chança dos ridículos, / Ao toque indecoroso nos testículos / De um torpe camerlengo!" (XAVIER, 1884, p. 35-36).

${ }^{19}$ Sobre esse erotismo decadentista, vale a pena lembrar o que diz Fernando Carvalho: "a poesia decadentista leva além o anti-religiosismo, exaltando o amor e a natureza em termos de pecado. Exaltará, aliás, não o amor, mas a luxúria, ou, por outro lado, é esse o nome que recebe quase sempre o amor na poesia decadente" (CARVALHO, 1962, p. 19). Está bem dizê-lo para um poeta místico como Wenceslau de Queirós, mas supor que a luxúria decadentista possa ser sempre traduzida em termos de pecado, quando boa parte do nosso decadentismo se identifica ainda com a poesia realista, me parece uma conclusão equivocada.

20 Segundo Glória Carneiro do Amaral, a responsabilidade desse procedimento profanatório (para quem, aliás, ele é adotado sobretudo com a intenção de chocar) é atribuída a Baudelaire, o que denuncia, mais uma vez, "uma assimilação equivocada do poeta francês, a quem a liturgia não seduzia de forma especial" (AMARAL, 1996, p. 222). 
À guisa de comparação, tomemos o trabalho de Medeiros e Albuquerque, um outro decadentista que serve, segundo os nossos historiadores, de ponte ao simbolismo. Canções da decadência e Pecados, dois livros seus publicados em 1889, não possuem a mesma linguagem litúrgica nem a mesma "beatificação do mal" que percebo em Rezas do Diabo. Não me parece, como quer Fernando Carvalho, que

as características do satanismo que encontramos na poesia de Wenceslau de Queirós já se encontram praticamente todas nos poemas de Canções da decadência, de Medeiros e Albuquerque. (CARVALHO, 1962, p. 17)

Exatamente porque em Rezas do Diabo descubro o "espírito místico" que nosso crítico associa ao simbolismo:

O simbolista, mesmo quando se mostra um insatisfeito ou descrente, exprime-se como um torturado prisioneiro da condição humana que aspira a uma libertação, a uma fuga para a região do sonho ou para qualquer paraíso que terá que buscar indefinidamente ou criar [...]. A poesia decadente não revela tal aspiração; é apenas revolta contra a condição terrena, revolta e não simples lamento, pois a vida é uma perpétua prisão e uma tortura perpétua à qual somente a morte pode pôr término, e a morte é aí encarada sem a menor dose de misticismo, não se envolve no mistério em que é envolvida pela poesia simbolista... (CARVALHO, 1962, p. 17)

Wenceslau de Queirós ultrapassa a revolta decadentista (e vale notar que a definição de Fernando Carvalho difere da proferida por Glória Carneiro do Amaral) e perambula filosoficamente pelas esferas do esoterismo. Medeiros e Albuquerque, por outro lado, sustenta a cosmovisão vazia que descubro em Fontoura Xavier e Carvalho Júnior e se insere perfeitamente no quadro decadentista; sua poesia não comporta nem um Deus e nem um Diabo (ou pelo menos um Deus que se importe com a existência humana). Assim afirma: "Eu só creio na Carne! O mais - é falso!" (ALBUQUERQUE, 1889b, p. 50). Ele é, como Fontoura Xavier e Carvalho Júnior, um cético.

São inúmeros os poemas em que Medeiros e Albuquerque associa a morte a um mergulho no abismo, a um perpétuo vazio, negando a existência de um céu, 
de um inferno ou qualquer coisa que o valha ${ }^{21}$ (aliás, como Fontoura Xavier). No soneto Resposta se encontra, talvez, a síntese mais completa da sua incredulidade:

O pessimismo deste tempo insano

Não é feito de lágrimas fingidas;

Já nem cabe do verso nas medidas,

Tanto ele inunda o coração humano!

Foi tão profundo o triste desengano

Das mortas crenças afinal perdidas,

Que no vácuo das almas doloridas

O tédio avolumou - negro tirano!

Nada ficou de pé... Veio a certeza

De que tudo na imensa Natureza

É simplesmente uma ilusão terrível.

Hoje até mesmo o pranto já nos cansa

Nesta medonha e trágica e impassível

Bancarrota suprema da esperança!

(ALBUQUERQUE, 1889b, p. 32)

Ou ainda em Nirvana, onde lamenta o silêncio divino e anseia por um aniquilamento universal:

\author{
E pois que o teu olhar \\ Senhor, não vem, não desce \\ E como um sol brilhante não aquece \\ A alma, em gelos de dúvida, a hesitar; \\ Pois que é baldado e vão \\ Tudo o que a mente aspira \\ E sentimos apenas a mentira \\ Ao cabo da mais lúcida ilusão; \\ Pois que não vemos Deus \\ Que nossa rota aclare \\ E nas sendas da vida nos ampare \\ E nos levante os olhos para os céus; \\ Pois que soçobra o Bem, \\ Como um baixel perdido, \\ E nas vagas da dor o homem caído \\ Nem um gozo sequer lutando tem;
}

\footnotetext{
${ }^{21}$ Há também, em Rezas do Diabo, alguns poemas assim. Veja-se o soneto $A$ caveira humana, por exemplo, uma composição de extremo ceticismo que apresenta a morte como um "nada", ou ainda Supremo Resgate, poema em que Wenceslau de Queirós anseia explicitamente por um vazio existencial que faça desaparecer o seu pensamento.
} 


\author{
Pois que o belo se esvai \\ - Sonho brilhante e puro - \\ E das auroras negras do futuro \\ Outro brilho quimérico não sai; \\ Pois que a verdade até \\ - Única luz restante - \\ Também treme e vacila agonizante, \\ Entre os escombros do porvir, em pé, \\ Que se extinga afinal \\ A vida derradeira! \\ E role e caia a Natureza inteira \\ Num aniquilamento universal! \\ (ALBUQUERQUE, 1889b, p. 38-39)
}

Resta a Medeiros e Albuquerque, curiosamente, o materialismo cientificista que combate, pois é incapaz de atravessar a concepção física do universo, e acaba caindo numa vertente do romantismo negro. Compõe um poema chamado D'a Noite na Taverna, em referência a Álvares de Azevedo, ecoando as discussões pessimistas e um tanto cientificistas da primeira parte do livro:

\footnotetext{
Que somos nós? Moléculas unidas

Ao sopro dos acasos que, perdidas,

Hão de volver ao seio da Matéria,

Passar e repassar no gigantesco

Mar temeroso, túrbido, dantesco,

Que banha a larga solidão etérea!

A alma de que falais, a essência pura

É sonho de momentos de loucura.

(ALBUQUERQUE, 1889b, p. 42)
}

Eis aí uma prévia do que se verá em Augusto dos Anjos, e que também está presente em um poema de Rezas do Diabo, Tedium Vitae: "Descansa em paz... Da terra na retorta / Tornar-se-á em alcaloides logo / Teu arcabouço de matéria morta" (QUEIRÓS, 1939, p. 131). Desse materialismo descrente fala Medeiros e Albuquerque, mas nem uma palavra sobre o Diabo. Seu ceticismo não encontra respaldo satânico, mas conduz ao gozo da carne, acima do bem e do mal, sem reflexões metafísicas - sem pecado, portanto. Wenceslau de Queirós, ao contrário, quando se refere à condição terrível da humanidade, remonta quase sempre a uma causa divina - ora acusa a indiferença de Deus frente às misérias do mundo e se une a Satanás em sua revolta; ora menciona o pecado original e 
lamenta as aspirações baldadas da humanidade; ora reconhece o papel definitivo do Diabo na perpetuação do mal entre os homens, e então parece se arrepender dos pecados.

\section{Conclusão}

Em suma, Wenceslau de Queirós parece introduzir uma nova vertente do satanismo decadista na literatura brasileira, diferente do que se encontra nos poetas realistas respingados de decadentismo (se é que se pode falar em satanismo nesse caso), e se afasta sensivelmente das primeiras manifestações pseudo-baudelairianas de Carvalho Júnior, Teófilos Dias, Fontoura Xavier e até mesmo Medeiros e Albuquerque. A sua obra, muito mais litúrgica e metafísica, muito menos crua e sensual que a dos poetas estritamente céticos, revela uma nova forma de interpretar o pensamento de Baudelaire (e, mais importante, não se restringe à emulação d'As flores do mal, como dá a entender o epíteto reducionista por que ficou famoso), acrescentando elementos temáticos e lexicais ao cabedal da nova geração, sem deixar de dialogar com todas as outras correntes do século XIX, do romantismo ao realismo. Ainda não há uma compilação definitiva de todo o seu trabalho, hoje perdido pelos jornais de dois séculos, o que impede que se tenha a real dimensão do que foi o seu satanismo e de como ele se encaixa na sua trajetória de poeta e intelectual. Aí está uma tarefa a exigir pesquisadores. Não tenho dúvida de que quem se incumbir dela revelará um Wenceslau de Queirós mais complexo do que o legado pela nossa historiografia.

\section{Referências}

ALBUQUERQUE, José Joaquim de Campos da Costa Medeiros e. Canções da decadência. Pelotas, Porto Alegre, Rio Grande: Carlos Pinto e Companhia, 1889a.

ALBUQUERQUE, José Joaquim de Campos da Costa Medeiros e. Pecados. Rio de Janeiro: Tipografia da Papelaria Parisiense, 1889b. 
AMARAL, Glória Carneiro do. Aclimatando Baudelaire. São Paulo: Annablume, 1996.

ASSIS, Joaquim Maria Machado de. A nova geração. Rio de Janeiro: Revista Brasileira, 1879.

Disponível

em:

https://www.literaturabrasileira.ufsc.br/documentos/?id=209670.

BOSI, Alfredo. História concisa da literatura brasileira. São Paulo: Cultrix, 1986.

CARNAVAL. Correio paulistano. São Paulo, 17 fev. 1920, p. 1.

CARVALHO, Fernando. Introdução. In: QUEIRÓS, Wenceslau de. Poesias escolhidas. São Paulo: Conselho Estadual de Cultura, 1962, p. 5-28.

COUSTÉ, Alberto. Biografia do diabo. Rio de Janeiro: Rosa dos Tempos, 1996.

COUTINHO, Afrânio. A literatura no Brasil. Volume 4. Rio de Janeiro: José Olympio; Niterói: UFF-Universidade Federal Fluminense, 1986.

FREIRE, Ezequiel. Revista dos Jornais. Correio Paulistano. São Paulo, 17 nov. 1887, p. 1.

LEITÃO, Joaquim. Ensaio Crítico: "Versos" - "Rezas do Diabo" de Wenceslau de Queiroz II. Correio Paulistano. São Paulo, 12 mar. 1898, p. 1.

LINK, Luther. O Diabo: a máscara sem rosto. São Paulo: Companhia das Letras, 1998.

MOISÉS, Massaud. Simbolismo (1893 - 1902). São Paulo: Cultrix, 1969.

PAPINI, Giovanni. // Diavolo. Florença: Vallecchi Editore, 1969.

PICCHIO, Luciana Stegagno. História da literatura brasileira. Rio de Janeiro: Nova Aguilar, 1997.

QUEIRÓS, Wenceslau de. Rezas do Diabo. São Paulo: Empresa gráfica da Revista dos Tribunais, 1939.

STANFORD, Peter. O Diabo: uma biografia. Rio de Janeiro: Gryphus, 2003.

TROVÃO, Lopes. Introdução. In: XAVIER, Fontoura. O régio saltimbanco. Rio de Janeiro, 1877.

VALLÈS, Jules. Charles Baudelaire. 1867. Disponível em: http://www.bmlisieux.com/litterature/valles/bodeler.htm.

XAVIER, Antônio Vicente da Fontoura. Opalas. Pelotas, Porto Alegre: Carlos Pinto e Companhia, 1884. 